\title{
Short Communication: The Effects of Histidine-Supplemented Drinking Water on the Performance of Lactating Dairy Cows
}

\author{
J. Doelman, N. G. Purdie, V. R. Osborne, ${ }^{1}$ and J. P. Cant \\ Department of Animal and Poultry Science, University of Guelph, Ontario, N1G 2W1 Canada
}

\section{ABSTRACT}

An experiment was conducted to test the hypothesis that a sufficient proportion of histidine (His) included in the drinking water of lactating cows bypasses the rumen to have an effect on milk synthesis. Eight dairy cows ( $45 \pm 15 \mathrm{~d}$ in milk) were given either 0 or $2.5 \mathrm{~g} / \mathrm{L}$ of His in the drinking water in a crossover design of two 7-d periods. Cows were offered a corn and alfalfa silage-based total mixed ration for ad libitum intake. Water was provided ad libitum to each cow in an individual automatic drinking vessel with a flow meter attached. Water intake tended to increase from 85.1 to 92.1 L/d when His was added. Concentrations of His in plasma samples collected on the last day of each period tended to increase from 14.6 to $21.6 \mu M$, corresponding to an estimated $0.4 \%$ bypass of the imbibed histidine. Other amino acid concentrations in plasma were not affected by His supplementation. Milk yield increased by $1.7 \mathrm{~L} / \mathrm{d}$ with His treatment, lactose yield increased by $90 \mathrm{~g} / \mathrm{d}$, and there were tendencies for protein yield to increase, fat percentage to decrease, and protein to fat ratio to increase. An improvement in postruminal histidine flow can influence milk production and composition but the proportion of imbibed water that bypasses the rumen will have to be increased to take advantage of drinking water as a vehicle to transfer His postruminally.

Key words: histidine, drinking water, milk composition, dairy cow

Histidine is an essential amino acid for which improvements in duodenal flow in lactating dairy cows have affected milk synthesis. Postruminal infusion of $0,2,4$, or $6 \mathrm{~g} / \mathrm{d}$ of His into cows fed a grass silage-based diet caused linear increases in milk, protein, and lactose yields and a linear decrease in milk fat (Korhonen et al., 2000). Infusion of $0,7,15$, or $30 \mathrm{~g} / \mathrm{d}$ of His i.v. into cows consuming a corn/alfalfa silage-based diet quadratically increased milk yield, linearly decreased

Received February 27, 2008.

Accepted June 6, 2008.

${ }^{1}$ Corresponding author: vosborne@uoguelph.ca fat yield and percentage, and had no effect on protein yield or content (Moon et al., 2004). Subtraction of 24 $\mathrm{g} / \mathrm{d}$ of His from an abomasal infusion of all amino acids decreased milk protein yield by $186 \mathrm{~g} / \mathrm{d}$ and increased milk fat yield by $181 \mathrm{~g} / \mathrm{d}$ (Weekes et al., 2006).

Water has been used as a vehicle to carry nutrients into the lactating cow (Osborne et al., 2002, 2008). Ruminal bypass of water has been estimated to be 5 to $25 \%$ of total water intake (Woodford et al., 1984; Café and Poppi, 1994) with variation attributed to rumen fill (Woodford et al., 1984) and to postnatal retention of the esophageal groove reflex (Ørskov and Benzin, 1969; Huber et al., 1982). The following experiment was designed to test the hypothesis that a sufficient proportion of His included in the drinking water of lactating cows will bypass the rumen to have an effect on milk production and composition. If bypass is sufficiently high, water supplementation could be an alternative to chemical protection of amino acids to increase postruminal delivery.

The University of Guelph Animal Care Committee approved all experimental procedures and ensured that the trial was conducted in accordance with guidelines of the Canadian Council on Animal Care (1993). Eight early-lactation ( $45 \pm 15$ DIM) Holstein dairy cows at $720 \pm 125 \mathrm{~kg}$ of BW were housed in individual tie stalls at the Elora Dairy Research Station (University of Guelph). Twice daily, cows were offered a corn silage- and haylage-based TMR ad libitum to provide a calculated $\mathrm{NE}_{\mathrm{L}}$ of $1.56 \mathrm{Mcal} / \mathrm{kg}$ and an estimated MP balance of $55 \mathrm{~g} / \mathrm{d}$ (NRC, 2001). As a percentage of total $\mathrm{DM}$, the ration was composed of $33.6 \%$ corn silage, $22.4 \%$ haylage, $19.4 \%$ high-moisture corn, $19.1 \%$ dairy supplement, and $5.5 \%$ mixed hay. The dairy supplement (on a DM basis) contained $1.47 \mathrm{Mcal} / \mathrm{kg}$ of $\mathrm{NE}_{\mathrm{L}}$, $38.56 \% \mathrm{CP}, 2.55 \% \mathrm{Ca}, 1.34 \% \mathrm{P}, 0.77 \% \mathrm{Mg}, 0.82 \% \mathrm{~S}, 136$ $\mathrm{mg} / \mathrm{kg}$ of $\mathrm{Cu}, 1.37 \mathrm{mg} / \mathrm{kg}$ of Se, $57.33 \mathrm{kIU} / \mathrm{kg}$ of vitamin A, $14.32 \mathrm{kIU} / \mathrm{kg}$ of vitamin D, and $217.32 \mathrm{IU} / \mathrm{kg}$ of vitamin E. Chemical composition of the diet was $42.3 \%$ $\mathrm{DM}, 17.6 \% \mathrm{CP}, 20.2 \% \mathrm{ADF}$, and $33.5 \% \mathrm{NDF}$.

Cows were randomly assigned to a treatment of 0 or $2.5 \mathrm{~g}$ of His/L of drinking water in a crossover design of two 7-d periods. The His concentration was calculated to deliver $35 \mathrm{~g} / \mathrm{d}$ of His postruminally, slightly greater 
Table 1. Effect of histidine treatment on water intake and milk production and composition $(\mathrm{n}=8)$

\begin{tabular}{lccc}
\hline & \multicolumn{2}{c}{ Histidine treatment } & \\
\cline { 2 - 3 } Item & $0 \mathrm{~g} / \mathrm{L}$ & $2.5 \mathrm{~g} / \mathrm{L}$ & $P$-value \\
\hline Water intake (L/d) & 85.1 & 92.1 & 0.06 \\
Milk yield (L/d) & 33.4 & 35.1 & 0.05 \\
Yield (g/d) & & & \\
Protein & 947 & 992 & 0.08 \\
Fat & 1,396 & 1,388 & 0.83 \\
Lactose & 1,596 & 1,686 & 0.03 \\
Percentage (\%) & & & \\
Protein & 2.86 & 2.84 & 0.47 \\
Fat & 4.18 & 3.95 & 0.11 \\
$\quad$ Lactose & 4.78 & 4.80 & 0.44 \\
Protein:fat & 0.69 & 0.73 & 0.13 \\
\hline
\end{tabular}

than the $30 \mathrm{~g} / \mathrm{d}$ of His given i.v. by Moon et al. (2004), assuming an average rumen bypass of $17 \%$ (Woodford et al., 1984; Café and Poppi, 1994) and a drinking water intake of $81.5 \mathrm{~L} / \mathrm{d}$ (Meyer et al., 2004). A concentrated solution of $200 \mathrm{~g} / \mathrm{L}$ of His was delivered by a liquid injector system (Model DI 150, Dosatron International Ltd., Clearwater, FL) at a rate of $12.5 \mathrm{~mL} / \mathrm{L}$ into water lines supplying automatic drinking bowls of the 4 cows on $2.5 \mathrm{~g} / \mathrm{L}$ of His. On both treatments, drinking water was provided ad libitum over the duration of the trial, and intakes were recorded continuously by flow meters according to Thomas et al. (2007).

Cows were milked in their stalls at 0500 and 1500 $\mathrm{h}$ daily. Milk volume was recorded and milk samples were collected for compositional analysis at each milking for the last $3 \mathrm{~d}$ of each period. Milk samples were refrigerated at $4^{\circ} \mathrm{C}$ until analyzed for protein, fat, and lactose content by infrared spectroscopy (AOAC, 1996). Samples of the TMR were collected daily and pooled into weekly composite samples for chemical analysis at a commercial feed laboratory (Agri-Food Laboratories, Guelph, Ontario, Canada). Blood samples were collected by tail venipuncture on the last day of each period before the evening milking. Plasma was separated by centrifugation and stored at $-20^{\circ} \mathrm{C}$ before amino acid analysis by reversed-phase HPLC (Waters Chromatography Division, 1986).

Variance in each observation $\left(\mathrm{Y}_{\mathrm{ijk}}\right)$ was analyzed by the GLM procedure of SAS version 9 (SAS Institute Inc., Cary, NC), according to:

$$
\mathrm{Y}_{\mathrm{ijk}}=\mu \ldots+\operatorname{cow}_{\mathrm{i}}+\operatorname{per}_{\mathrm{j}}+\operatorname{trt}_{\mathrm{k}}+\varepsilon_{\mathrm{ijk}},
$$

where $\mu \ldots=$ mean, cow $_{\mathrm{i}}=\mathrm{ith}$ cow effect (i= 1 to 8$) ;$ per $_{\mathrm{j}}$ $=$ th period effect $(\mathrm{j}=1$ to 2$)$; $\operatorname{trt}_{\mathrm{k}}=\mathrm{kth}$ His inclusion effect ( $\mathrm{k}=1$ to 2 ); and $\varepsilon_{\mathrm{ijk}}=$ random variation, assumed to be $\mathrm{N}\left(0, \sigma^{2}\right)$. Significance was declared at $P \leq 0.05$ and a tendency at $0.05<P<0.15$. When $P<0.15$, the
Table 2. Effect of histidine treatment on plasma amino acid concentrations $(\mathrm{n}=8)$

\begin{tabular}{lrrr}
\hline & \multicolumn{2}{c}{ Histidine treatment } & \\
\cline { 2 - 3 } Amino acid, $\mu M$ & $0 \mathrm{~g} / \mathrm{L}$ & $2.5 \mathrm{~g} / \mathrm{L}$ & $P$-value \\
\hline Glu & 38.7 & 34.1 & 0.20 \\
Ser & 39.7 & 39.9 & 0.92 \\
Asn & 14.2 & 14.7 & 0.77 \\
Gly & 221.7 & 183.9 & 0.19 \\
Gln & 218.3 & 214.7 & 0.81 \\
Tau & 40.9 & 36.0 & 0.15 \\
His & 14.6 & 21.6 & 0.06 \\
Cln & 58.8 & 55.7 & 0.47 \\
Thr & 27.4 & 29.6 & 0.31 \\
Ala & 163.7 & 141.5 & 0.24 \\
Arg & 36.9 & 37.1 & 0.91 \\
Pro & 82.5 & 80.3 & 0.69 \\
Tyr & 45.8 & 47.3 & 0.74 \\
Val & 187.8 & 181.8 & 0.76 \\
Ile & 84.6 & 79.4 & 0.54 \\
Leu & 153.5 & 141.9 & 0.50 \\
Phe & 43.1 & 41.6 & 0.48 \\
Trp & 6.5 & 6.0 & 0.60 \\
Orn & 11.2 & 19.9 & 0.45 \\
Lys & 55.9 & 54.5 & 0.73 \\
\hline
\end{tabular}

presence of carryover from period 1 to period 2 was investigated with a $t$-test applied to the treatment differences observed when the first treatment was $0 \mathrm{~g} / \mathrm{L}$ of His compared with $2.5 \mathrm{~g} / \mathrm{L}$ as the first treatment. Carryover was not significant $(P>0.15)$.

There was a tendency $(P=0.06)$ for water intake to increase from 85.1 to $92.1 \mathrm{~L} / \mathrm{d}$ with His treatment (Table 1). Actual His intakes from the drinking water averaged 0 and $230 \mathrm{~g} / \mathrm{d}$ for the 2 treatments, respectively.

Milk lactose yield increased $(P=0.03)$ with $2.5 \mathrm{~g} / \mathrm{L}$ His from 1,596 to $1,686 \mathrm{~g} / \mathrm{d}$, and total milk yield increased $(P=0.05)$ from 33.4 to $35.1 \mathrm{~L} / \mathrm{d}$. Milk protein yield tended $(P=0.08)$ to increase from 947 to $992 \mathrm{~g} / \mathrm{d}$, and fat percentage tended $(P=0.11)$ to decrease from 4.18 to $3.95 \%$. Other milk component percentages were not affected so that the $2.5 \mathrm{~g} / \mathrm{L}$ His treatment tended to increase the protein to fat ratio $(P=0.13)$. Of all the amino acid concentrations in plasma (Table 2), only that of His was affected, showing a tendency to increase by $7 \mu M(P=0.06)$ or $50 \%$ with His in the water.

Korhonen et al. (2000) infused postruminal doses of $0,2,4$, and $6 \mathrm{~g} / \mathrm{d}$ of His into lactating cows and observed graded increases in plasma His concentrations. Assuming a kinetic relationship between concentration of $\mathrm{His}$ in plasma and flux out of or into the plasma pool, we used the regression of concentration against His infusion rate from Korhonen et al. (2000) to estimate ruminal bypass of imbibed His in our experiment. According to the regression slope of $7.3 \mu M$ per $\mathrm{g} / \mathrm{d}$ of His, the 7 $\mu M$ increase in plasma His concentration observed in 
our study corresponds to a postruminal flow of $1.0 \mathrm{~g} / \mathrm{d}$ His or $0.4 \%$ of the supplemental intake of $230 \mathrm{~g} / \mathrm{d}$. This percentage is substantially lower than the average of $17 \%$ observed for water bypass out of the rumen of pastured steers offered water for only short periods (Café and Poppi, 1994) and lactating dairy cows temporarily withheld water (Woodford et al., 1984). The data from Korhonen et al. (2000) provide a benchmark to estimate postruminal flow of His based on its plasma concentrations, although other differences between the studies (e.g., plasma pool size, efficiency of retention of His in body and milk proteins) could be responsible for the low estimate of ruminal bypass calculated this way.

By monitoring plasma glucose concentrations in 2 -yr-old heifers given glucose in the drinking water, Huber et al. (1982) noted that training the animals to suckle by nipple pail through prolonged withdrawal of water significantly increased the proportion bypassing the rumen. The musculature forming the esophageal groove that is responsible for rumen bypass in the milk-fed preruminant can be induced to contract in the adult by the posture of the animal while drinking, site of delivery into the esophagus, and chemical composition of the fluid consumed (Ørskov, 1972). Woodford et al. (1984) conclude that the greater volume of rumen bypass water in cows withheld water for 4.5 vs. $9 \mathrm{~h}$ may have been due to greater fill of the rumen before drinking. Restricting water availability to short intervals within a day induces greater drinking volumes without affecting total daily intake (Thomas et al., 2007) and may improve the bypass percentage. Therefore, although the estimated efficiency of transfer of imbibed His to plasma was low, there may be strategies that encourage closure of the esophageal groove and a greater bypass of imbibed nutrients.

Despite the low rumen bypass estimate, plasma His concentration increased enough to elicit a change in milk production and composition. The increases in milk, protein, and lactose yields observed were noted previously with $6.5 \mathrm{~g} / \mathrm{d}$ of abomasal His (Vanhatalo et al., 1999) and with 4 levels of postruminal His between 0 and $6 \mathrm{~g} / \mathrm{d}$ (Korhonen et al., 2000). The increase in milk yield of $1.7 \mathrm{~L} / \mathrm{d}$ for a $7 \mu M$ increase in plasma His was 7.5 times greater than the increase of $0.23 \mathrm{~L} / \mathrm{d}$ expected from the regression of milk yield on plasma His concentration from the dose-response experiment of Korhonen et al. (2000), for which slope $=0.032 \mathrm{~kg} / \mathrm{d}$ per $\mu M$. Similarly, the $90 \mathrm{~g} / \mathrm{d}$ increase in lactose yield was 6.3 times greater than that expected from the slope of $2.04 \mathrm{~g} / \mathrm{d}$ per $\mu M$ calculated from Korhonen et al. (2000). These discrepancies might indicate that the previous estimate of $0.4 \%$ His bypass could be magnified 6 - or 7 -fold to between 2 and $3 \%$ bypass.
In addition to effects on milk component yields, the decrease in fat percentage and an increased protein:fat ratio have also been reported previously (Vanhatalo et al., 1999; Korhonen et al., 2000; Cant et al., 2001; Moon et al., 2004; Weekes et al., 2006). All the effects on milk components have been noted on diets based on a variety of forages including grass, legume, and corn silages. We conclude that His appears to induce a general increase in the protein to fat ratio of milk. The proportion of imbibed water that bypasses the rumen must be improved to take advantage of drinking water as a vehicle to carry His past the rumen.

\section{ACKNOWLEDGMENTS}

A special thanks to Anneliese Krueger, Laura Wright, and Peter Robertson (Elora Dairy Research Center, University of Guelph) for helping with sampling and taking care of the animals. Thanks to Karl de Ridder and Anna-Kate Shoveller (Univerrsity of Guelph) for amino acid analyses. Financial support for this work was provided by the Dairy Farmers of Ontario, NSERC Canada, and the Ontario Ministry of Agriculture and Food. John Doelman was the recipient of a Keiffer Vitamin Scholarship.

\section{REFERENCES}

AOAC. 1996. Official Methods of Analysis. 16th ed. Association of Official Analytical Chemists, Arlington, VA

Café, L. M., and D. P. Poppi. 1994. The fate and behavior of imbibed water in the rumen of cattle. J. Agric. Sci. 122:139-142.

Canadian Council on Animal Care. 1993. Guide to the Care and Use of Experimental Animals. CCAC, Ottawa, Ontario, Canada.

Cant, J. P., D. R. Trout, F. Qiao, and B. W. McBride. 2001. Milk composition responses to unilateral arterial infusion of complete and histidine-lacking amino acid mixtures to the mammary glands of cows. J. Dairy Sci. 84:1192-1200.

Huber, J. T., F. E. Standaert, and R. S. Emery. 1982. Rumen bypass of protein through suckling of liquids by lactating heifers. J. Dairy Sci. 65:1163-1169.

Korhonen, M., A. Vanhatalo, T. Varvikko, and P. Huhtanen. 2000 Responses to graded postruminal doses of histidine in dairy cows fed grass silage diets. J. Dairy Sci. 83:2596-2608.

Meyer, U. M., M. Everinghoff, D. Gadeken, and G. Flachowsky. 2004. Investigations on the water intake of lactating dairy cows. Livest. Prod. Sci. 90:117-121.

Moon, Y. H., P. H. Luimes, L. E. Wright, C. A. Toerien, and J. P. Cant 2004. Intravenous histidine infusion affects milk composition in lactating dairy cows. J. Dairy Sci. 87(Suppl. 1):218. (Abstr.)

NRC. 2001. Nutrient Requirements of Dairy Cattle. 7th rev. ed. National Acad. Press, Washington, DC.

Ørskov, E. R. 1972. Technology so that the rumen is bypassed following artificial rearing. Page 627 in 2nd World Congress on Animal Feeding. 1: General Reports. Madrid, Spain. Int. Vet. Assoc. Anim. Prod.

Ørskov, E. R., and D. Benzin. 1969. Studies on the oesophageal groove reflex in sheep and on the potential use of the groove to prevent fermentation of food in the rumen. Br. J. Nutr. 23:415-421.

Osborne, V. R., L. E. Leslie, and B. W. McBride. 2002. Effect of supplementing glucose in drinking water on the energy and 
nitrogen status of the transition dairy cow. Can. J. Anim. Sci. $82: 427-433$.

Osborne, V. R., S. Radhakishnan, N. E. Odongo, A. R. Hill, and B. W. McBride. 2008. Effects of supplementing fish oil in the drinking water of dairy cows on production performance and milk fatty acid composition. J. Anim. Sci. 86:720-729.

Thomas, L. C., T. C. Wright, A. Formusiak, J. P. Cant, and V. R. Osborne. 2007. Use of flavored drinking water in calves and lactating dairy cattle. J. Dairy Sci. 90:3831-3837.

Vanhatalo, A., P. Huhtanen, V. Toikonen, and T. Varvikko. 1999. Response of dairy cows fed grass silage diets to abomasal infusions of histidine alone or in combinations with methionine and lysine. J. Dairy Sci. 82:2674-2685.

Waters Chromatography Division. 1986. Pico-Tag amino acid analysis system operator's manual. Millipore Corporation, Waters Chromatography Division, Milford, MA.

Weekes, T. L., P. H. Luimes, and J. P. Cant. 2006. Responses to amino acid imbalances and deficiencies in lactating dairy cows. J. Dairy Sci. 89:2177-2187.

Woodford, S. T., M. R. Murphy, C. L. Davis, and K. R. Holmes. 1984. Ruminal bypass of drinking water in lactating cows. J. Dairy Sci. 67:2471-2474. 